\title{
The Problematics of Female Sexuality in Alice Munro's Short Stories
}

\author{
Jeḷena Antoṇeviča \\ Daugavpils University, Latvia
}

\begin{abstract}
The present research discerns the concept of female sexuality suggested by Luce Irigaray as exemplified in Alice Munro's short stories. A. Munro is widely recognized to have been among the first authors, especially in her breakthrough Lives of Girls and Women (1971), to portray the desire of young women for sexual autonomy. Nevertheless, the majority of female protagonists in her stories experience the denial, oppression and negation of female sexuality. Women in Munro's stories try to gain a sense of freedom from the pressures and prejudices dictated by the double standards of men's society. Through her characters she shows the drama of the private lives of women and collective female experience in general.

The research also contains the debate of a French feminist's Luce Irigaray's ideas with Freud's and Lacan's understanding of female sexuality. In Irigaray's "This sex which is not one" (1977) she defies Freud's and Lacan's analyses of sexual relations and proposes a female sexuality which is self-referential and disconnected from "masculine parameters" of sexual conceptualization.
\end{abstract}

Keywords: deconstruction, depression, feminine, psychoanalysis, relationship 